Yüzüncü Y1l Üniversitesi
Tarim Bilimleri Dergisi

Araştırma Makalesi (Research Article)

\title{
Çilek Yapraklarının Antioksidan Enzim Aktiviteleri Üzerine Farklı Hormon Uygulamalarının Etkisi
}

\section{Müttalip GÜNDOĞDU1 ${ }^{1}$, Selma KURU BERK ${ }^{2}$, Mustafa Kenan GEÇER ${ }^{* 3}$, Selma KIPÇAK ${ }^{4}$, Özlem ÇAKMAKCI ${ }^{5}$}

${ }^{1}$ Bolu Abant İzzet Baysal Üniversitesi, Ziraat ve Doğa Bilimleri Fakültesi, Bahçe Bitkileri Böl., Bolu, Türkiye

${ }^{2}$ Bolu Abant İzzet Baysal Üniversitesi, Mudurnu Süreyya Astarcı Meslek Yüksekokulu, Bolu, Türkiye

${ }^{3}$ Bolu Abant İzzet Baysal Üniversitesi, Ziraat ve Doğa Bilim. Fak., Tohum Bilimi ve Tek. Bölümü, Bolu, Türkiye

${ }^{4}$ Van Yüzüncü Yıl Üniversitesi, Başkale Meslek Yüksekokulu, Van, Türkiye

${ }^{5}$ Van Yüzüncü Yıl Üniversitesi, Ziraat Fakültesi, Bahçe Bitkileri Bölümü, Van, Türkiye

*Sorumlu yazar e-posta: mkenangecer@hotmail.com

\section{Makale Bilgileri}

Geliș: 24.12.2018

Kabul: 01.04.2019

Online Yayınlanma 28.06.2019

DOI: $10.29133 /$ yyutbd.501793

\section{Anahtar kelimeler}

Antioksidan enzimler,

Bitkisel hormonlar,

Çilek,

MDA
Öz: Bu çalışma, 5 farklı çilek çeşidinde (Albion, Aromas, Honeoye, Seascape, Sweet Ann) dişardan metil jasmonat (MeJA) ve gibberalik asit $\left(\mathrm{GA}_{3}\right)$ uygulamasının antioksidan enzim aktiviteleri üzerine etkisini belirlemek amacıyla yapılmıştır. 50ppm ve $100 \mathrm{ppm}$ dozlarında $\mathrm{GA}_{3}$ ve 0.25 , 0.50 ve 1.00 $\mathrm{mM}$ dozlarında MeJA uygulaması yapraktan uygulanmıştır. Alınan yaprak örneklerinde katalaz (KAT), süperoksidaz dismutaz (SOD) ve malondialdehit (MDA) miktarları okunmuştur. Sweet Ann çeşidi en yüksek KAT ve SOD aktivitesine sahipken, Honeoye çeşidi en düşük değerlere sahip olmuştur. CAT aktivitesi Seascape ve Aromas çeşitlerinde azalma göstermiş diğer çeşitlerde uygulama ve doza bağlı olarak değişkenlik görülmüştür. SOD miktarı Albion ve Seascape çeşitlerinde her uygulama ile artış kaydetmiştir. KAT ve SOD aktivitesinin aksine, MDA konsantrasyonu en fazla Honeoye çeşidinde, en düşük Sweet Ann çeșidinde belirlenmiștir. Yapılan araștırmada, $\mathrm{GA}_{3}$ ve $\mathrm{MeJa}$ uygulamaları çilek çeșitlerine ve uygulanma dozlarına bağlı olarak yaprakların enzim ve MDA içeriklerini etkilediği saptanmıştır.

\section{Effect of Different Hormone Applications on Antioxidant Enzyme Activities of Strawberry Leaves}

\section{Article Info}

Received: 24.12.2018

Accepted: 01.04.2019

Online Published 28.06.2019

DOI: 10.29133/yyutbd.501793

Keywords

Antioxidant enzymes,

Plant hormones,

Strawberry,

MDA
Abstract: This study was carried out to determine the effect of the application of methyl jasmonate (MeJa) and gibberellic acid $\left(\mathrm{GA}_{3}\right)$ on the antioxidant enzyme activity in 5 different strawberry cultivars (Albion, Aromas, Honeoye, Seascape, Sweet Ann). The application of $50 \mathrm{ppm}$ and 100ppm $\mathrm{GA}_{3}$ and $0.25,0.50$, and $1.00 \mathrm{mM}$ doses MeJA was applied as foliar spray. Catalase (CAT), superoxide dismutase (SOD) and malondialdehyde MDA levels were determined in the collected leaf. Samples sweet Ann cultivar had the highest CAT and SOD activity while Honeoye cultivar had the lowest values. CAT activity was decreased in Seascape and Aromas cultivars, and it was observed that CAT activity variability according to application and dose in other cultivars. The amount of SOD has increased with each application in the Albion and Seascape cultivars. In contrast to CAT and SOD activity, MDA concentration was determined the highest in Honeoye and the lowest in Sweet Ann. The present study, it was determined that the hormone $\left(\mathrm{GA}_{3}\right.$, MeJa) applications affected the enzyme and MDA contents depending on the cultivars and the doses of the hormones. 


\section{Giriş}

Çilek, ülkemizde ve dünyada insanlar tarafindan sevilerek tüketilen bir meyve türüdür. Doğal olarak meydana gelen bitki büyüme düzenleyiciler çilekte de olduğu gibi bitkilerin çok çeşitli fizyolojik ve biyokimyasal süreçleri üzerine tesir etmektedir (Sharma ve Singh, 2009; Kumar ve ark., 2014). Gibberellinler bitkilerde; vejetatif büyüme, meyve iriliği ve meyve eti sertliğini arttırma, tohum ve tomurcuk dormansisini kırma (Baktır, 2010), çiçeklenmeyi teşvik etme ve soğuklama ihtiyacını karşılama (Kacar ve ark., 2006) gibi birçok fizyolojik ve morfolojik faaliyeti etkilemektedir. Jasmonatlar ise stoma açılması, büyüme, çiçek tomurcuğu oluşumu ve tohum çimlenmesini engellemekte ancak meyve olgunlaşmasını, yaprak yaşlanmasını, renk pigmentlerinin üretimini ve protein sentezini arttırmaktadır (Creelman ve Mullet, 1997; Wang, 1999).

Hücre içi faaliyetler süperoksit radikali $\left(\mathrm{O}_{2}^{-}\right)$, hidrojen peroksit $\left(\mathrm{H}_{2} \mathrm{O}_{2}\right)$, hidroksil radikalleri $\left(\mathrm{OH}^{-}\right)$ve singlet oksijen $\left({ }^{1} \mathrm{O}_{2}\right)$ gibi çeşitli reaktif oksijen türlerinin (ROT) oluşumuna neden olmaktadır (Özen ve Onay, 2007; Kabay ve Şensoy, 2016). Antioksidan enzimler, bitki metabolik aktiviteleri sırasında oluşan reaktif oksijen türlerinin (ROT) süpürülmesinde önemli işlevlere sahiptir. SOD, $\mathrm{O}_{2}{ }^{-}$ 'nin büyük bir temizleyicisidir ve onu $\mathrm{H}_{2} \mathrm{O}_{2}$ ve $\mathrm{O}_{2}$ 'ye dönüştürmekte, KAT ve Peroksidaz (POD) ise $\mathrm{H}_{2} \mathrm{O}_{2}$ 'yi $\mathrm{H}_{2} \mathrm{O}^{\prime}$ ya dönüştürmektedir (Camp ve ark., 1997). Reaktif oksijen türleri, hücre içerisinde bulunan membran lipitlerini, nükleik asitleri, proteinleri, klorofilleri ve makro molekülleri tahrip etmektedirler. Lipid peroksidasyon hücre zarında hasara, hücre sıvısının kaybolmasına ve ileri aşamada hücrenin ölümüne yol açmaktadır. Bu işlem sonucu MDA üretimi ile sonuçlanmaktadır. Yüksek miktarda MDA miktarı hücre zarının zarar gördügünü, düşük miktarda MDA ise hücre zarı yapısının zarar görmediğini veya az seviyede etkilendiğini göstermektedir (Dhindsa ve Mathowe, 1981; Yonghua ve ark., 2005; Premachandra ve ark., 1991).

Bitki büyüme düzenleyicilerin antioksidan metabolizmasında yer alan enzimlerin aktivitelerinde değişkenlik gösterdiğini ifade eden birçok çalışma vardır. Jasmonik asit (JA) uygulaması enzim aktivitesini tetiklemekte ve özellikle stres koşulları karşısında bu etki artarak bitkilerin savunma mekanizmasında artışa neden olmaktadır (Li ve ark., 2012). Dışsal JA uygulaması ile KAT ve SOD aktivitesinde artış olduğu bildirilmektedir (Günalp, 2011). Giberellik asit uygulaması ile de KAT ve SOD aktivitesinde ve MDA miktarlarında değişkenlik olduğu yapılan çalışmalarda vurgulanmaktadır (Uzal, 2017). Ayrıca bu aktivitelerin çeşide bağlı olarak da değişkenlik gösterdiği ifade edilmektedir (Yong ve ark., 2008; Günalp, 2011; Ergin, 2012).

Yapılan bu araştırmada, farklı çilek çeşitlerine ait yaprakların KAT, SOD ve MDA içerikleri üzerine giberellik asit ve metil jasmonat uygulamalarının etkisi incelenmiştir.

\section{Materyal ve Yöntem}

Araştırma Bolu ili Mudurnu ilçesinde bulunan çilek bahçesinde 2017 yılında yürütülmüştür. Materyal olarak Albion, Aromas, Sweet Ann, Honeoye ve Seascape olmak üzere 5 farklı çeşit kullanılmıştır. Yaz dikimi ile dikilen frigo fidelerde giberellik asit ve metil jasmonat uygulaması yapılmıştır. Uygulamalar verim çağındaki bitkilerde ilk çiçeklenme döneminde ve ilk çiçeklenmeden iki hafta sonra yapılmıştır. Kontrol grubuna herhangi bir uygulama yapılmamışıtır. Giberellik asit $50 \mathrm{ppm}$ ve $100 \mathrm{ppm}$ 'lik doz olarak yapraklara püskürtme şeklinde uygulanmıştır. MeJA uygulaması ise yapraktan sprey şeklinde $0.25,0.50$ ve $1.00 \mathrm{mM}$ dozlarında uygulanmıştır.

\subsection{Enzim aktivasyonu}

Dondurulmuş yaprak örnekleri, öncelikle $5 \mathrm{ml}$ soğuk $50 \mathrm{mM}$ potasyum fosfat, $0.1 \mathrm{mM} \mathrm{Na}$ EDTA (pH: 7.6) ile homojenize edildikten sonra $4^{\circ} \mathrm{C}$ sıcaklıkta 30 dakika süreyle 18000 devir/dakika santrifüj edilmiştir. Enzim ekstraksiyonunun tüm aşamaları $+4^{\circ} \mathrm{C}^{\prime}$ de gerçekleştirilmiştir.

Süperoksit dismutaz, spektrofotometrik olarak 560nm dalga boyunda nitro blue tetrazolium'un (NBT) inhibisyonu ile tespit edilmiştir (Jebara ve ark., 2010). Ünite olarak NBT’un \%50'sinin indirgenmesi SOD aktivitesi olarak belirlenmiştir. Katalaz aktivitesi, Çakmak ve Marschner (1992) metoduna göre 240nm dalga boyunda $\mathrm{H}_{2} \mathrm{O}_{2}$ 'nin kaybolmasının izlenmesi ile belirlenmiştir. 


\subsection{Lipid peroksidasyonu (MDA)}

Çilek bitkilerinden alınana $0.5 \mathrm{~g}$ yaprak örneği \%0.1'lik trikloroasetik asit (TCA) ile homojenize edilmiş ve hemen arkasından 15000 devir/dakika 15dakika santrifüj edilmiştir. Santrifüj işlemi tamamlandıktan sonra örneğin üst fazından $1 \mathrm{ml}$ alınıp, üzerine $2 \mathrm{ml} \% 20$ ’lik TCA içerisinde çözülmüş \%0.5'lik tiobarbiturik asit (TBA) eklenmiştir. $\mathrm{Bu}$ işlemden sonra $95^{\circ} \mathrm{C}$ 'de 30 dakika bekletildikten sonra hızlı bir şekilde buz banyosunda soğutulup 10000 devir/dakika 10 dakika santrifüj yapılan karışımın 532 ve $600 \mathrm{~nm}$ dalga boyunda absorbansı belirlenmiş ve $155 \mathrm{mM} / \mathrm{cm}$ molar absorbsiyon katsayısı kullanılarak MDA içeriği hesaplanmıştır (Heath ve Packer, 1968).

Araştırma sonuçları SPSS istatistik programı kullanılarak Varyans analizi ile $\mathrm{P}<0.05$ önemlilik derecesine göre değerlendirilmiş olup önemli bulunan ortalamalar Duncan Çoklu Karşılaştırma Testi'ne göre gruplandırılmıştır.

\section{Bulgular}

Çilek yapraklarına dışardan metil jasmonat ve giberellik asit uygulaması yapılarak antioksidan enzim aktivitesinin araştırıldığı bu çalışmada, her iki uygulamanın farklı aktivite gösterdiği görülmüş̧ür. Ayrıca çeşitlere bağlı olarak uygulamalar arasında da farklılıklar söz konusu olmuştur.

\subsection{KAT ve SOD enzim aktivitesi}

Çizelge 1'e göre, KAT enzim aktivitesi çeşide ve uygulamaya bağlı olarak değişkenlik göstermiştir. Albion çeşidinde MeJA'nın düşük doz uygulamasında artış olurken Sweet Ann çeşidinde $1.0 \mathrm{mmol}$ metil jasmonat ve giberellik asidin tüm dozlarında artış kaydedilmiştir. Honeoye çeşidine düşük doz GA3 ve MeJA uygulaması ile KAT aktivitesi artış kaydetmiştir. Metil jasmonat uygulaması ile bu artışın \%200 oranına vardığı görülmektedir (Şekil 1). Seascape ve Aromas çeşitlerinde genel olarak her iki uygulama ile azalma görülmüştür. Bu azalma metil jasmonat uygulamalarında \%50'den daha fazla olmuştur (Şekil 1). Her iki uygulama kıyaslandığında, en fazla KAT enzim aktivitesi $1.0 \mathrm{mM}$ MeJA uygulamasında $0.0137 \mathrm{mmol} \mathrm{g}^{-1} \mathrm{TA}$ olarak Sweet Ann çeşidinde elde edilmiştir. Giberellik asit uygulamasında ise en yüksek değer Sweet Ann çeşidinde 100ppm doz uygulamasında (0.0123 mmol g ${ }^{-1}$ TA) kaydedilmiştir. KAT enzim aktivitesinde en çok azalma Seascape çeşidinde metil jasmonat uygulamalarında $\left(0.002 \mathrm{mmol} \mathrm{g}^{-1} \mathrm{TA}\right)$ gerçekleşmiştir (Çizelge 1, Şekil 1).

Bitki büyüme düzenleyicilerin uygulanması ile SOD aktivitesinde farklılıklar görülmüştür. Honeoye çeşidi en az SOD aktivitesi gösteren çeşit olurken Sweet Ann çeşidi en yüksek SOD değerlerine sahip çeşit olmuştur (Çizelge 1). Albion, Aromas ve Seascape çeşitlerinde en yüksek aktivite 50ppm dozunda GA3 doz uygulaması yapılan bitkilerden elde edilmiştir. Ayrıca Albion ve Seascape çeşitlerinde her uygulama ile artış sağlanmıştır (Şekil 2). En yüksek SOD aktivitesi 323.23 U $\mathrm{mg}^{-1}$ TA değeri ile Sweet Ann çeşidinde $0.5 \mathrm{mM}$ metil jasmonat uygulamasında kaydedilirken en az aktivite Honeoye çeşidinde $0.25 \mathrm{mM}$ metil jasmonat uygulaması $\left(67.83 \mathrm{U} \mathrm{mg}^{-1} \mathrm{TA}\right)$ ile kaydedilmiştir (Çizelge 1). Tüm uygulamalar içerisinde en yüksek artış \%100'den daha fazla olarak 50ppm GA3 uygulamasında elde edilmiştir. Ayrıca metil jasmonat uygulaması ile en fazla artış ise $1.0 \mathrm{mM}$ uygulamalarında bulunmuştur (Şekil 2). SOD aktivitesinde, giberellik asit uygulaması ile en yüksek değerler $50 \mathrm{ppm}$ doz ile sağlanırken, metil jasmonat uygulaması ile 0.5 ve $1.0 \mathrm{mM}$ dozları ile sağlanmıştır (Çizelge 1).

\subsection{Lipid peroksidasyon (MDA konsantrasyonu)}

MDA miktarı, giberellik asit ve metil jasmonat uygulaması ile değişkenlik göstermiştir. Ayrıca çeşitler arasında da farklılıklar söz konusu olmuştur. Honeoye çeşidi daha fazla MDA miktarına sahip çeşit olarak belirlenirken, Sweet Ann çeşidi daha az MDA miktarına sahip çeşit olarak belirlenmiştir (Çizelge 1). Sadece Aromas çeşidinde tüm uygulamalar ile \%5-25 arasında değişen artış sağlanmıştır. Ayrıca, Honeoye çeşidinde de $1.0 \mathrm{mM}$ MeJA uygulaması hariç diğer uygulamalarda artış kaydedilmiştir. Kontrole göre en fazla artış Sweet Ann çeşidinde $0.5 \mathrm{mM}$ MeJA uygulaması ile \%40 oranında elde edilmiştir. Ancak Sweet Ann çeşidinin aksine, 0.5mM MeJA uygulaması Albion ve Seascape çeşitlerinde MDA içeriklerinde \%30'dan fazla azalma bulunmuştur (Şekil 3). Metil jasmonat 
uygulaması en yüksek $0.25 \mathrm{mM}$ doz uygulaması ile $29.42 \mu \mathrm{mol} \mathrm{\textrm {g } ^ { - 1 }}$ TA MDA içeriği Honeoye çeşidinde ölçülürken, giberellik asit uygulamasının 100ppm dozu ile MDA miktarı Honeoye çeşidinde $30.88 \mu \mathrm{mol} \mathrm{g}^{-1}$ TA olarak ölçülmüştür (Çizelge 1). Aromas ve Honeoye çeşitleri dışında, giberellik asit uygulamasının MDA miktarı üzerine olumsuz etki ettiği görülmektedir (Çizelge 1, Şekil 3).

Çizelge 1. MeJA ve GA 3 uygulamasının KAT, SOD aktivitesi ve MDA miktarı üzerine etkisi.

\begin{tabular}{|c|c|c|c|c|c|c|c|}
\hline \multicolumn{8}{|c|}{$\mathrm{KAT}_{\mathrm{mmol} \mathrm{g}} \mathrm{g}^{-1} \mathrm{TA}$} \\
\hline Cecit & Kontrol & $0.25 \mathrm{mM}$ & $0.5 \mathrm{mM}$ & $1.0 \mathrm{mM}$ & 50ppm & 100nמm & Ortalama \\
\hline 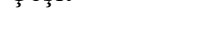 & & MeJA & MeJA & MeJA & $\mathrm{GA}_{3}$ & 200 & - \\
\hline Albion & 0.0063 & 0.0090 & 0.0083 & 0.0057 & 0.0043 & 0.0053 & 0.0065 \\
\hline Aromas & 0.0090 & 0.0027 & 0.0050 & 0.0027 & 0.0077 & 0.0077 & 0.0056 \\
\hline Honeoye & 0.0040 & 0.0120 & 0.0097 & 0.0040 & 0.0067 & 0.0033 & 0.0066 \\
\hline Seascape & 0.0070 & 0.0020 & 0.0023 & 0.0073 & 0.0063 & 0.0067 & 0.0053 \\
\hline Sweet Ann & 0.0063 & 0.0050 & 0.0057 & 0.0137 & 0.0067 & 0.0123 & 0.0083 \\
\hline Ortalama & 0.0064 & 0.0061 & 0.0062 & 0.0067 & 0.0063 & 0.0071 & \\
\hline p değeri (Çeşit) & \multicolumn{7}{|c|}{0.452} \\
\hline $\begin{array}{l}\text { p değeri } \\
\text { (Hormon) }\end{array}$ & \multicolumn{7}{|c|}{0.996} \\
\hline p değeri $(C ̧ x H)$ & \multicolumn{7}{|c|}{0.241} \\
\hline \multicolumn{8}{|c|}{ SOD U mg ${ }^{-1} \mathrm{TA}$} \\
\hline Albion & 120.50 & 165.97 & 145.67 & 203.26 & 245.63 & 168.38 & $174.90 \mathrm{~B}$ \\
\hline Aromas & 207.20 & 151.20 & 214.71 & 118.63 & 220.08 & 170.41 & $178.79 \mathrm{~B}$ \\
\hline Honeoye & 109.26 & 67.83 & 104.39 & 143.59 & 130.94 & 102.72 & $109.79 \mathrm{C}$ \\
\hline Seascape & 123.23 & 224.33 & 153.98 & 187.26 & 225.20 & 159.29 & $178.88 \mathrm{~B}$ \\
\hline Sweet Ann & 273.88 & 250.83 & 323.23 & 207.84 & 229.20 & 250.01 & $255.83 \mathrm{~A}$ \\
\hline Ortalama & 163.93 & 172.03 & 188.39 & 172.11 & 210.21 & 170.16 & \\
\hline p değeri (Çeşit) & \multicolumn{7}{|c|}{0.001} \\
\hline $\begin{array}{l}\text { p değeri } \\
\text { (Hormon) }\end{array}$ & \multicolumn{7}{|c|}{0.391} \\
\hline p değeri $(C ̧ x H)$ & \multicolumn{7}{|c|}{0.306} \\
\hline \multicolumn{8}{|c|}{ MDA $\mu \mathrm{mol} \mathrm{g}^{-1} \mathrm{TA}$} \\
\hline Albion & 22.49 & 23.23 & 14.49 & 18.54 & 19.78 & 17.42 & 19.33 BC \\
\hline Aromas & 19.29 & 24.43 & 22.79 & 24.09 & 20.73 & 21.85 & 22.37 B \\
\hline Honeoye & 22.75 & 29.42 & 24.95 & 22.11 & 27.57 & 30.88 & $26.28 \mathrm{~A}$ \\
\hline Seascape & 22.71 & 22.59 & 16.04 & 23.83 & 18.79 & 17.20 & 20.19 BC \\
\hline Sweet Ann & 14.88 & 19.57 & 21.03 & 17.68 & 13.85 & 17.76 & $17.46 \mathrm{C}$ \\
\hline Ortalama & 20.51 & 23.85 & 19.86 & 21.25 & 20.14 & 21.02 & \\
\hline p değeri (Çeşit) & \multicolumn{7}{|c|}{0.001} \\
\hline $\begin{array}{l}\text { p değeri } \\
\text { (Hormon) }\end{array}$ & \multicolumn{7}{|c|}{0.190} \\
\hline p değeri $(C ̧ x H)$ & \multicolumn{7}{|c|}{0.226} \\
\hline
\end{tabular}




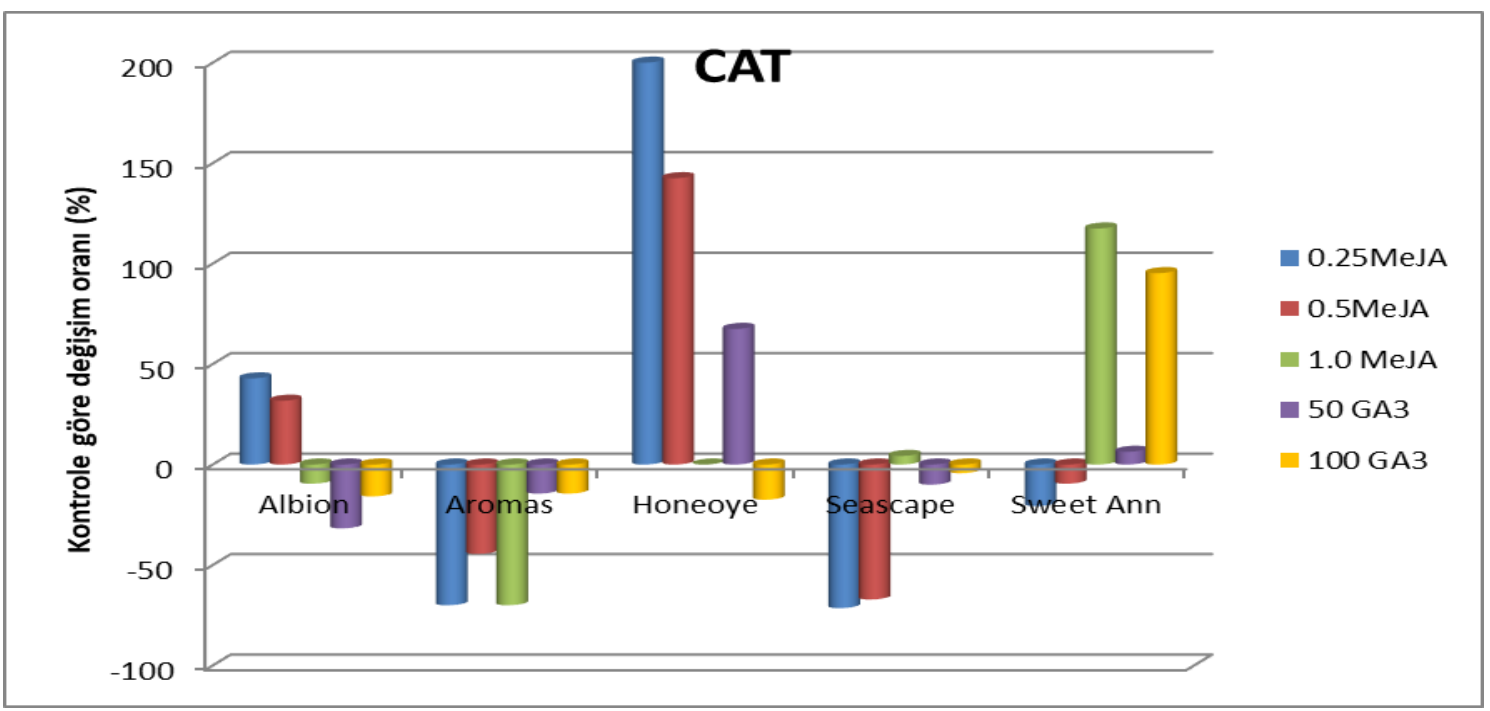

Şekil 1. MeJA ve GA $\mathrm{G}_{3}$ uygulaması ile CAT enzim aktivitesinin değişim oranı.

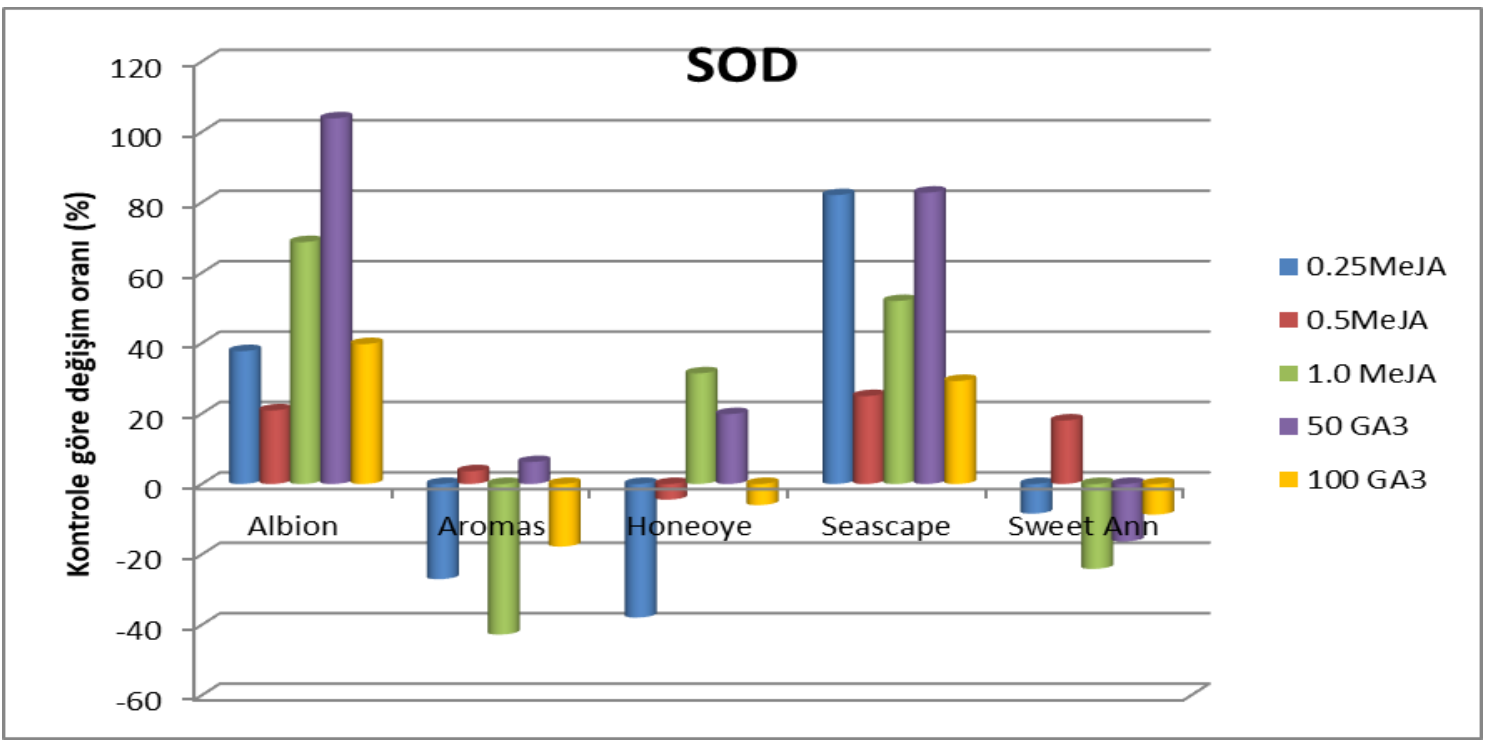

Şekil 2. MeJA ve GA $\mathrm{G}_{3}$ uygulaması ile SOD enzim aktivitesinin değişim oranı.

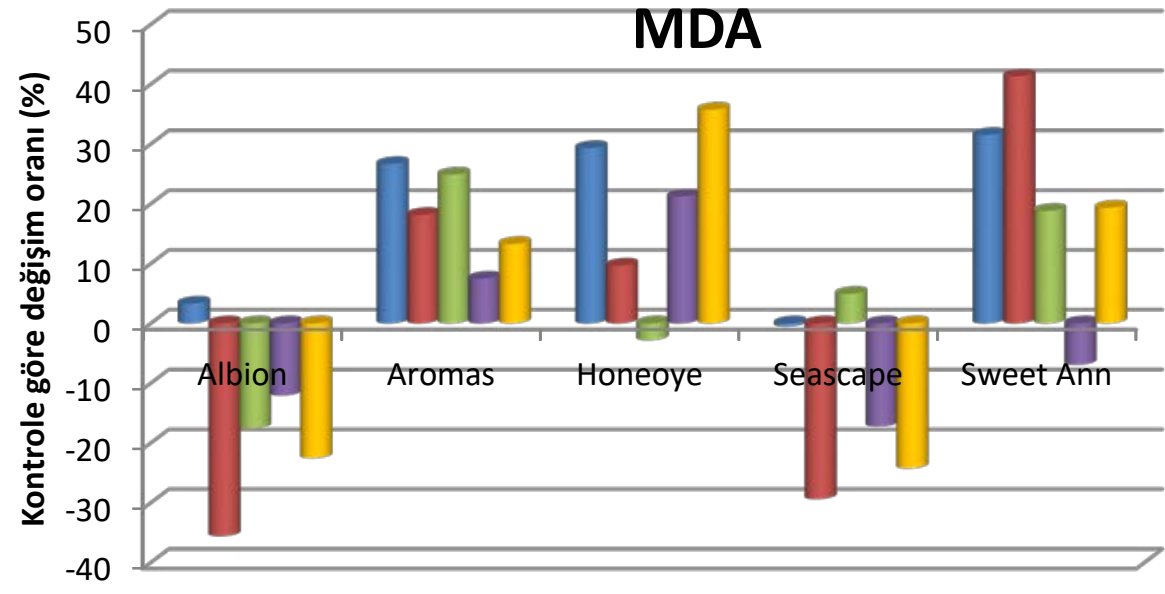

0.25MeJA

0.5MeJA

1.0 MeJA

$50 \mathrm{GA3}$

$100 \mathrm{GA3}$

Şekil 3. MeJA ve $\mathrm{GA}_{3}$ uygulaması ile MDA miktarının değişim oranı 


\section{Tartışma ve Sonuç}

Enzim aktivitesinin çeşit, büyüme düzenleyici ve ekolojik duruma göre değişkenliği hakkında pek çok çalışma yapılmıştır. Bazı araştırmacılar, $0.1 \mathrm{mM}$ MeJA uygulaması ile KAT aktivitesinin arttığını ancak doz arttıkça bu aktivitede azalma olduğunu ifade etmişlerdir (Yan ve ark., 2013). Wang (1999) susuzluğa bağlı olarak azalan KAT ve SOD aktivitesinin metil jasmonat uygulaması ile arttığını vurgulamıştır. Farklı hormon ve dozlarının kallus kültüründe kullanıldığı bir çalışmada; SOD ve KAT aktiviteleri, $\mathrm{GA}_{3}$ dozunun en yüksek olduğu kırmızı film altında yetiştirilen çilek eksplantlarında en yüksek ve en az giberellik asit içeren sarı film altındaki eksplantlarda en düşük olarak bulunmuştur (Yonghua ve ark., 2005). Bizim çalışmamızda KAT aktivitesi çeşide bağlı olarak değişmekte ancak bu çalışma ile benzer şekilde SOD aktivitesi genel olarak giberellik asit ile artış göstermektedir. Benzer şekilde soya fasulyesinde yürütülen araştırmada, giberellik asit uygulaması ile SOD ve KAT aktivitesinin arttığ 1 ancak bu artışın $50 \mathrm{mM}$ dozda daha fazla olduğu ifade edilmiştir (Sofy, 2016). Yong ve ark. (2008) ise iki farklı çilek çeşidinin düşük sıcaklığa maruz kalması ile SOD ve KAT aktivitesinin ani bir artış gösterdiğini ancak daha sonra KAT aktivitesinde çeşide bağlı olarak değişen önemli bir azalma olduğunu bildirmişlerdir. Çalışmamızla uyumlu olarak çeşidin yanı sıra uygulamalarında farklılıklar ortaya çıkardığı göz ardı edilmemelidir. Yine farklı bir çalışmada, soğuğa maruz kalan çilek bitkilerinde KAT aktivitesinin \%50'den daha fazla arttı̆̆ 1 görülmüştür. Benzer şekilde; Aromas çeşidi ile yapılan farklı bir araştırmada, KAT enzimi soğuk kış aylarında yaz aylarına göre daha yüksek olduğu ve bitkilerin savunma mekanizması olarak bu enzimi kullandıkları belirtilmiştir (Turhan ve ark., 2012). Farklı bir çalışmada, çilek bitkilerine salisilik asit uygulaması ile enzim aktivitesinin (KAT ve SOD) artarak hücre zararının azaldığı ve kuraklığa karşı daha dayanıklı olduğu da yapılan çalışmalarda belirtilmiştir (Sun ve ark., 2013b). Çeşit ve bitki büyüme düzenleyiciler dışında, bitkilerin maruz kaldıkları ekolojik koşullarında enzim aktivitesini etkilediği görülmektedir. Bu çalışmaların aksine Toyonaka çilek çeşidinde yapılan bir çalışmada, bitkiye verilen antibiyotiklerin KAT ve SOD aktivitesini düşürdüğü ve MDA miktarını arttırarak hücre zararını arttırdığı belirtilmiştir (Qin ve ark., 2011).

Yapılan bir çalışmada, kadmiyum (Cd) toksisitesine maruz bırakılan kırmızı biberlerde artan metil jasmonat dozu ile MDA miktarının da arttığı ifade edilmiştir (Yan ve ark., 2013). Yine hastalıklı bitkilerde MeJA uygulaması ile MDA konsantrasyonun azaldığ 1 ve metil jasmonatın hücre zararını azalttı̆̆ bildirilmiştir (Sun ve ark., 2013a). Giberellik asit uygulaması yapılan biberde, KAT ve SOD aktivitesinin arttığı ancak MDA miktarının azaldığı ayrıca $\mathrm{GA}_{3}$ uygulamasının hücre hasarı üzerine istatistiksel olarak çok fazla etkisinin olmadığı ifade edilmiştir (Uzal, 2017). Bizim bulgularımızdan çok düşük olmak kaydı ile Zhang ve ark. (2008) çilekte yaptıkları çalışmada MDA miktarının 3.12$4.87 \mu \mathrm{mol} \mathrm{g}{ }^{-1} \mathrm{TA}$ arasında değiştiğini bildirmişlerdir.

Wang (2000) çilek bitkisine uyguladığı metil jasmonat ile MDA miktarının azalırken SOD ve

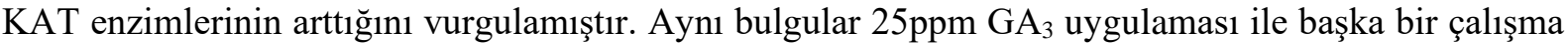
sonucunda da elde edilmiştir (Shan ve ark., 2007). Bizim çalışmamızda çeşide bağlı olarak değişmek kaydı ile $\mathrm{GA}_{3}$ uygulaması ile genel bir azalma tespit edilmiştir. Yapılan başka bir çalışmada, Camarosa çilek çeşidinde soğuk zararına bağlı olarak MDA hasarının arttığı ifade edilmiş̧tir (Gülen ve ark., 2008). Ancak Wang (1999) susuzluğa bağlı olarak artan hücre zararının (MDA) metil jasmonat uygulaması ile azaldığını belirtmiştir.

$\mathrm{Bu}$ araştırmada, çilek bitkilerine yapraktan metil jasmonat ve giberellik asit uygulamalarının KAT ve SOD enzim aktiviteleri ile MDA miktarını etkilediği tespit edilmiştir. Bu etki her ne kadar istatistiksel olarak önemsiz çıksa da çeşide ve uygulamaya bağlı olarak değişkenlik gözlenmiştir. Bunun yanında bazı çeşitlerde uygulamalara bağlı olarak enzim aktivitesinin artış gösterdiği tespit edilmiştir. Enzim aktivitesindeki artışın bitkilerde hücre zararını önlediğine yönelik farklı araştırmacılar tarafından birçok çalışma yapılmıştır.

\section{Kaynakça}

Baktır, İ. (2010). Bitki Büyüme Düzenleyicileri Özellikleri ve Tarımda Kullanımları. Hasad Yayıncılık, İstanbul. 
Çakmak, I., \& Marschner, H. (1992). Magnesium deficiency and high light intensity enhance activities of superoxide dismutase, ascorbate peroxidase, and glutathione reductase in bean leaves. Plant Physiol., 98, 1222-1227.

Camp, W. V., Inza, D., \& Montagu, M. V. (1997). The regulation and function of tobacco superoxide dismutase free radical, Biol. Med. 23, 515-520.

Creelman, R. A., \& Mullet, J. E. (1997). Biosynthesis and action of jasmonates in plants. Annu Rev Plant Physiol Plant Mol Biol, 48, 355-381.

Dhindsa, R. S., \& Mathowe, W. (1981). Drought tolerance in two mosses: correlated with enzymatic defence against lipid peroxidation. J. of Exp. Bot. 32 (126), 79-91.

Ergin, S. (2012). Yüksek sicakllk stresinin çilek bitkisinde enzimatik ve enzimatik olmayan antioksidanlar ile protein metabolizmasina etkileri. (Doktora tezi), Uludağ Üniversitesi Fen Bilimleri Enstitüsü, Bursa.

Gülen, H., Çetinkaya, C., Kadığlu, M., Kesici, M., Cansey, A., \& Eriş, A. (2008). Peroxidase activity and lipid peroxidation in strawberry (Fragaria $\mathrm{X}$ ananassa) plants under low temperature. Journal of Biology Environment Science, 2 (6), 95-100.

Günalp, B. (2011). Patlican (Solanum melongena L.) embriyo kültüründe, jasmonik asit ve tuz stresi etkileşiminin incelenmesi. (Yüksek Lisans Tezi), Anakara Üniversitesi Fen Bilimleri Enstitüsü, Ankara.

Heath, R. L., \& Packer, L. (1968). Photoperoxidation in isolated chloroplasts: I. Kinetics and stoichiometry of fatty acid peroxidation. Arch. Biochem. Biophys., 125 (1), 189-198.

Jebara, S., Jebara, M., Limam, F., \& Aouani, M. E. (2005). Changes in ascorbate peroxidase, catalase, guaiacol peroxidase and superoxide dismutase activities in common bean (Phaseolus vulgaris) nodules under salt stress. J. of Plant Physiol. 162 (8), 929-936.

Kabay, T., \& Şensoy, S. (2016). Kuraklık stresinin bazı fasulye genotiplerinde oluşturduğu enzim, klorofil ve iyon değişimleri. Yüzüncü Yll Üniversitesi Tarım Bilimleri Dergisi, 26 (3), 380395.

Kacar, B., Katkat, A. V., \& Öztürk, Ş. (2006). Bitki Fizyolojisi. Nobel Yayınları. 2. Baskı. Ankara.

Kumar, R., Saravanan, S., Jasrotia, A., Bakshi, P., Shah, R., \& Raina, V. (2014). Influence of gibberellic acid and blossom removal on flowering and yield of strawberry (Fragaria $\times$ ananassa Duch.) cv. belrubi. International Journal of Agricultural Sciences, 10, 272-275.

Li, D. M., Guo, Y. K., Li, Q., Zhang, J., Wang, X. J., \& Bai, J. G. (2012). The pretreatment of cucumber with methyl jasmonate regulates antioxidant enzyme activities and protects chloroplast and mitochondrial ultrastructure in chilling-stressed leaves. Science Horticulture, 143, 135-143.

Özen, H. Ç., \& Onay, A. (2007). Bitki Fizyolojisi. Nobel Yayın Dağıtım, Ankara.

Premachandra, G. S., Soneoka, H., Kanaya, M., \& Ogata, S. (1991). Cell membrane stability and leaf surface wax content as affected by increasing water deficits in maize. J.Exp. Bot., 42, 167171.

Qin, Y.H., Teixeira da Silva, J. A., Bi, J. H., Zhang, S. L., \& Hu, G. B. (2011). Response of in vitro strawberry to antibiotics. Plant Growth Regulator, 65, 183-193.

Shan, S., Liu, G., Li, S., \& Miao, P. (2007). Effects of IAA, GA3 and 6-BA applied in autumn on plant quality of strawberry. Journal of Fruit Science, 24 (4), 545-548.

Sharma, R. R., \& Singh, R. (2009). Gibberellic acid influences the production of malformed and button berries, and fruit yield and quality in strawberry (Fragaria ananassa Duch.). Scientia Horticulturae 119, 430-433.

Sofy, M. R. (2016). Effect of Gibberellic Acid, Paclobutrazol and Zinc on Growth, Physiological Attributes and the Antioxidant Defense System of Soybean (Glycine max) under Salinity Stress. International Journal of Plant Research, 6 (3), 64-87.

Sun, D., Lu, X., Hu, Y., Li, W., Hong, K., Mo, Y., Cahill, D. M., \& Xie, J. (2013a). Methyl jasmonate induced defense responses increase resistance to Fusarium oxysporum f. sp. cubense race 4 in banana. Scientia Horticulturae, 164, 484-491.

Sun, C. H., Wang, D., Hu, Y. L., Li, X. H., Zhang, W. D., Sun, J., \& Gao, X. L. (2013b). Effects of salicylic acid on physiological characteristics of strawberry leaves under drought stress. Europ. J. Hort. Science, 78 (3), 106-111. 
Turhan, E., Aydoğan, Ç., Baykul, A., Akoğlu, A., Evrenosoğlu, Y., \& Ergin, S. (2012). Apoplastic antioxidant enzymes in the leaves of two strawberry cultivars and their relationship to coldhardiness. Not Bot Horti Agrobo, 40 (2), 114-122.

Uzal, O. (2017). The effect of $\mathrm{GA}_{3}$ applications at different doses on lipidperoxidation, chlorophyll, and antioxidant enzyme activities in pepper plants under salt stress. Fresenius Environmental Bulletin, 26 (8), 5283-5288.

Wang, S. Y. (1999). Methyl jasmonate reduces water stress in strawberry. Journal of Plant Growth Regulator, 18, 127-134.

Wang, S. Y. (2000). Effect of methyl jasmonate on water stress in strawberry. Acta Horticulture, 516, 89-96.

Yan, Z., Chen, J., \& Li, X. (2013). Methyl jasmonate as modulator of Cd toxicity in Capsicum frutescens var. fasciculatum seedlings. Ecotoxicology and Environmental Safety, 98, 203-209.

Yong, Z., Hao-Ru, T., \& Ya, L. (2008). Variation in Antioxidant Enzyme Activities of Two Strawberry Cultivars with Short-term Low Temperature Stress. World Journal of Agricultural Sciences, 4 (4), 458-462.

Yonghua, Q., Shanglong, Z., Asghar, S., Lingxiao, Z., Qiaoping, Q., Kunsong, C., \& Changjie, X. (2005). Regeneration mechanism of Toyonoka strawberry under different color plastic films. Plant Science, 168, 1425-1431.

Zhang, Y., Luo, Y., Hou, Y., Jiang, H., Chen, Q., \& Tang, H. (2008). Chilling acclimation induced changes in the distribution of $\mathrm{H}_{2} \mathrm{O}_{2}$ and antioxidant system of strawberry leaves. Agricultural Journal, 3(4), 286-291. 